\title{
ANALISIS PENGARUH EKONOMI KREATIF DALAM PENYERAPAN TENAGA KERJA DI KOTA MEDAN
}

\author{
${ }^{1}$ Sri Endang Rahayu, ${ }^{2}$ Bella Avista \\ ${ }^{1,2}$ Fakultas Ekonomi \& Bisnis Universitas Muhammadiyah Sumatera Utara \\ Email: ${ }^{1}$ sriendang@umsu.ac.id \\ ²belaavista19@gmail.com
}

\begin{abstract}
ABSTRAK
Penelitian ini bertujuan untuk menganalisis bagaimana pengaruh ekonomi kreatif terhadap penyerapan tenaga kerja di kota Medan dengan menggunakan analisis deskriptif kualitatif. Sampel yang digunakan adalah metode judgement sampling yang merupakan bagian dari purposive sampling. Penelitian ini menggunakan data primer dengan kuesioner, wawancara terhadap 40 responden pemilik usaha industri kreatif di kota Medan. Hasil penelitian ini menunjukkan bahwa sektor kerajinan adalah sektor yang paling banyak menyerap tenaga kerja dan peneliti menemukan banyaknya kendala yang dihadapi oleh pemilik usaha industri kreatif sehingga mereka sulit mengembangkan usahanya.
\end{abstract}

Kata Kunci : Ekonomi kreatif, Penyerapan tenaga kerja

\section{ABSTRACT}

This study aims to analyze how the influence of the creative economy on employment in the city of Medan by using qualitative descriptive analysis. The sample used is judgment sampling method which is part of purposive sampling. This study uses primary data with interview questionnaires on 40 respondents of creative industry business owners in the city of Medan. The results of this study indicate that the handicraft sector is the sector that absorbs the most workforce and researchers find many obstacles faced by creative industry business owners so that they have difficulty developing their business.

Keywords: creative economy, labor absorption

\section{PENDAHULUAN}

\subsection{Latar Belakang}

Sektor industri dalam perekonomian suatu negara sudah lama dikenal sebagai salah satu motor penggerak pembangunan ekonomi, hal ini sudah sejak lama menjadi perhatian bagi pemerintahan Indonesia. Pada era pemerintahan yang pernah ada, strategi pembangunan ekonomi yang disetir oleh rencana pembangunan lima tahun (Repelita) difokuskan pada industrialisasi. Hal ini telah menjadikan perekonomian Indonesia pada dekade 70-an hingga 80-an mengalami kemajuan dari perekonomia tradisional dengan pertanian sebagai andalan utama ke perkonomian yang bersifat lebih modern yang didominasi oleh sektorsektor berbasi teknologi (non-primer). Dalam kurun waktu yang cukup lama, perkembangan ekonomi Indonesia kini dihadapkan pada era ekonomi baru yaitu era informasi yang disertai dengan banyaknya penemuan baru di bidang teknologi informasi dan komunikasi serta globalisasi ekonomi.

Dalam konteks kebijakan industri masa kini, negara berkembang tidak bisa mengandalkan daya saingnya di bidang industri manufaktur, dengan memanfaatkan keunggulan komparatif dalam bentuk biaya tenaga kerja yang 
lebih rendah dan sumber daya alam yang melimpah. Hal tersebut telah membuat banyak negara di dunia beralih ke pemberdayaan SDM yang kreatif, yang pada akhirnya pada tahun 1990-an dimulailah era ekonomi baru yang menitikberatkan pada kreativitas dan informasi sebagai pemain utama, yang popular disebut ekonomi kreatif yang digerakkan oleh sektor industri yang disebut Industri Kreatif.

Ekonomi kreatif adalah penciptaan nilai tambah yang berbasis ide yang lahir dari kreatifitas sumber daya manusia (orang kreatif) dan berbasis pemanfaatan ilmu pengetahuan termasuk warisan budya dan tehnologi (Kementrian Pariwisata dan Ekonomi Kreatif, 2014).

Konsep Ekonomi Kreatif merupakan sebuah bagian dari era ekonomi baru yang memberdayakan informasi, kreativitas dan teknologi dengan mengandalkan ide dan pengetahuan dari Sumber Daya Manusia (SDM) sebagai faktor produksi utama dalam kegiatan ekonominya. Struktur perekonomian dunia mengalami transformasi dengan cepat seiring dengan pertumbuhan ekonomi, dari yang tadinya berbasis Sumber Daya Alam (SDA) sekarang menjadi berbasis SDM, dari era pertanian ke era industri dan informasi.

Secara umum, alasan kuat mengapa industri kreatif perlu untuk dikembangkan disebabkan pengaruh dari setiap sektor industri kreatif ini memiliki kontribusi yang signifikan bagi perekonomian suatu negara yang dapat menciptakan iklim bisnis yang baik serta memperkuat citra dan identitas suatu bangsa dalam pemanfaatan sumber daya yang terbarukan yang memiliki dampak sosial yang positif. Kondisi ekonomi yang diharapkan oleh Indonesia adalah ekonomi yang berkelanjutan. Keberlanjutan yang dimaksud adalah kemampuan untuk beradapatasi terhadap kondisi geografis dan tantangan ekonomi baru, yang pada akhirnya menghasilkan keberlanjutan pertumbuhan. Ekonomi Kreatif yang didalamnya terdapat industri-industri dalam menciptakan inovasi memiliki daya tawar yang tinggi di dalam ekonomi berkelanjutan karena individu-individunya memilki modal kreativitas (creative capital) yang mereka gunakan untuk menciptakan inovasi-inovasi.

Pengembangan ekonomi nasional ke arah industri kreatif merupakan bagian dari optimisme aspirasi untuk mendukung Master plan Percepatan dan Perluasan Pembangunan Ekonomi Indonesia (MP3EI) demi mewujudkan Indonesia menjadi negara maju. Di dalamnya terdapat pemikiranpemikiran, cita-cita, imajinasi dan mimpi untuk menjadi masyarakat dengan kualitas hidup yang tinggi, sejahtera dan kreatif.

Industri kreatif di Indonesia semakin tumbuh dan beragam, di tunjukkan dengan semakin meningkatnya jumlah usaha kreatif dan semakin banyak minat masyarakat untuk berkecimpung di Industri kreatif dari waktu ke waktu. Pada tahun 2013 tercatat sebanyak 5,4 juta usaha bergerak di industri kreatif yang pada umumnya merupakan usaha kecil dan menengah. Gairah industri ini didorong karena semakin besanya permintaan akan produk dan karya kreatif lokal serta ketersediaan teknologi yang mudah diakses dan cukup terjangkau oleh UKM. 
Relatif rendahnya jiwa kewirausahaan menjadi tantangan dalam peningkatan daya saing industri kreatif. Seringkali orang kreatif bukanlah seorang wirausaha yang baik, sehingga orang kreatif perlu didampingi oleh rekan bisnis yang membantu dirinya untuk dapat mengembangkan bisnis kreatif yang memanfaatkan bisnis kreatifitas dan inovasi yang dimilikinya, oleh karena itu dalam menjalankan usaha kreatif dan menjaga keberlangsungan usaha, tidak hanya membutuhkan kemampuan untuk membaca peluang pasar dan manajemen bisnis yang baik. Walaupun demikian saat ini semakin banyak orang kreatif yang memulai usaha kreatifnya sendiri dan sudah menyadari pentingnya pemahaman tentang manajemen bisnis.

Secara geografis Kota Medan terletak pada $3,30^{\circ}-3,43^{\circ}$ Lintang Utara dan 98,350-98,44o Bujur Timur dengan luas 26.510 hektare $(265,10$ $\mathrm{km}^{2}$ ) atau 3,6\% dari keseluruhan wilayah Sumatera Utara. Dengan demikian, dibandingkan dengan kota atau kabupaten lainnya, Medan memiliki luas wilayah yang relatif kecil. Di bagian barat dan timur, Medan berbatasan dengan Kabupaten Deli Serdang yang merupakan salah satu daerah yang kaya dengan Sumber Daya alam (SDA) khususnya di bidang perkebunan dan kehutanan, dan di bagian utara Medan berbatasan langsung dengan Selat Malaka yang diketahui merupakan salah satu jalur lalu lintas terpadat di dunia.

Letak geografis Kota medan ini sangat strategis sebagai gerbang (pintu masuk) kegiatan perdagangan barang dan jasa, baik perdagangan domestik maupun luar negeri (ekspor-impor).
Faktor ini memungkinkan Medan untuk berhubungan secara langsung dengan wilayah-wilayah di propinsi Sumatera Utara, Pulau Sumatera, wilayah nasional Indonesia, bahkan dengan negara-negara tetangga yang menjadikan kota Medan secara ekonomi mampu mengembangkan berbagai kerjasama dan kemitraan yang sejajar, saling menguntungkan, saling memperkuat dengan daerahdaerah sekitarnya. Hal ini pula yang mendorong perkembangan Medan sebagai pusat kegiatan ekonomi, perdagangan, transportasi laut, darat dan udara, pendidikan, perindustrian, pelayanan kesehatan, dan lain-lain.

Pertumbuhan ekonomi di kota Medan terus mengalami peningkatan yaitu dari tahun 2011 sampai tahun 2015, tahun 2011 Rp 97.675.579.10, tahun $2012 \quad \mathrm{Rp}$ 105.161.998.30, Tahun 2013 sebesar Rp 110.795.416.30,tahun 2014 sebesar Rp 117.525.059.42 dan ditahun 2015 sebesar Rp 124.269.931.93.

Penduduk Kota Medan memiliki ciri yaitu yang meliputi unsur agama, suku/etnis, budaya dan keragaman (plural) adat istiadat. Keanekaragaman etnis di Medan terlihat dari jumlah masjid, gereja dan vihara yang banyak tersebar di seluruh kota. Hal ini memunculkan karakter sebagian besar penduduk Kota Medan bersifat terbuka. Komponen kependudukan lainnya umumnya menggambarkan berbagai dinamika sosial yang terjadi di masyarakat, baik secara sosial maupun kultural. Menurunnya tingkat kelahiran (fertilitas) dan tingkat kematian (mortalitas), meningkatnya arus perpindahan antar daerah (migrasi) dan proses urbanisasi, mempengaruhi kebijakan kependudukan yang diterapkan. 
Tabel 1.1

Jumlah Penduduk menurut Kelompok Umur dan Jenis Kelamin di Kota Medan tahun 2013

\begin{tabular}{cccr}
\hline $\begin{array}{c}\text { Kelompok } \\
\text { Umur }\end{array}$ & Laki-Laki & Perempuan & \multicolumn{1}{l}{ Jumlah } \\
\hline $0-4$ & 102.196 & 98.201 & 200.397 \\
\hline $5-9$ & 96.337 & 91.372 & 187.709 \\
\hline $10-14$ & 91.390 & 87.510 & 178.900 \\
\hline $15-19$ & 103.859 & 108.422 & 212.281 \\
\hline $20-24$ & 118.924 & 126.359 & 245.283 \\
\hline $25-29$ & 97.223 & 99.374 & 196.597 \\
\hline $30-34$ & 85.323 & 89.072 & 174.395 \\
\hline $35-39$ & 78.318 & 81.867 & 160.185 \\
\hline $40-44$ & 70.658 & 73.439 & 144.097 \\
\hline $45-49$ & 60.138 & 62.736 & 122.874 \\
\hline $50-54$ & 50.235 & 52.945 & 80.321 \\
\hline $55-59$ & 39.767 & 40.554 & 53.703 \\
\hline $60-64$ & 26.374 & 27.329 & 33.793 \\
\hline $65-69$ & 15.567 & 18.226 & 23.238 \\
\hline $70-74$ & 10.149 & 13.089 & 18.563 \\
\hline $75+$ & 6.935 & 11.628 & $\mathbf{2 . 1 3 5 . 5 1 6}$
\end{tabular}

Sumber : Badan Pusat Statistik 2013

Berdasarkan data kependudukan tahun 2013, penduduk Medan mencapai 2.135.516 jiwa, dengan kepadatan penduduk $8.009 \mathrm{jiwa} / \mathrm{km}^{2}$, di mana jumlah wanita lebih besar dari pria (1.082.123 jiwa > 1.053.393). Usia 15-64 tahun merupakan kelompok usia produktif atau kelompok usia aktif secara ekonomis yang mencapai 2.059.992 jiwa.

Provinsi Sumatera Utara memiliki beragam etnis yakni etnis Karo, Toba, Simalungun, Pakpak, Melayu, Nias, Mandailing dan Angkola, Jawa, Minang, Aceh, Tionghoa dan lainnya. Setiap etnis memiliki bahasa daerahnya masing-masing. Setiap etnis memiliki aneka budaya sendiri, hingga membentuk Sumut menjadi daerah yang memiliki kekayaan budaya yang beraneka ragam dalam bentuk adat istiadat, seni tradisional, dan bahasa daerah. Namun semuanya menyatu menjadi penduduk Sumatera Utara dan identik dengan warga Sumatera Utara.

Dari segi agama, Sumut juga sangat beragam. Semua agama formal yang diakui secara nasional ada di daerah ini. Di luar itu ada juga agama non formal yang juga berkembang seperti Parmalin. Gambaran ini cukup menunjukkan betapa beragamnya kehidupan budaya dan kehidupan keberagamaan di daerah ini. Dan Medan sebagai ibu kota provinsi 
adalah tempat berkumpulnya semua keragaman ini, baik dari sisi budaya dan keberagamaan. Sebagai kota besar di provinsi ini, Medan menjadi tujuan warga dari daerah, baik untuk bekerja mencari nafkah, menetap ataupun sekedar singgah. Oleh karenanya bisa kita bayangkan, kompleksnya kehidupan sosial dalam masyarakat yang sangat heterogen seperti ini.

Kondisi sosial yang terbagi atas pendidikan, kesehatan, kemiskinan, keamanan dan ketertiban, agama dan lainnya, merupakan faktor penunjang dan penghambat bagi pertumbuhan ekonomi Kota Medan. Demikian juga halnya dengan kemiskinan, dimana kemiskinan merupakan salah satu masalah utama pengembangan kota yang sifatnya kompleks dan multi dimensional yang fenomenanya dipengaruhi oleh berbagai faktor yang saling berkaitan, antara lain : tingkat pendapatan, kesehatan, pendidikan, lokasi, gender dan kondisi lingkungan. Kemiskinan bukan lagi dipahami hanya sebatas ketidak mampuan ekonomi, tetapi juga kegagalan memenuhi hak-hak dasar dan perbedaan perlakuan bagi seseorang atau sekelompok orang dalam menjalani kehidupan secara bermartabat.

Berdasarkan data BPS tahun 2015 jumlah penduduk miskin di Kota Medan mencapai angka 207.30 ribu jiwa. Salah satu yang menyebabkan kemiskinan adalah pengangguran yang mencapai 108.243 orang pada tahun 2015. Kelompok usia produktif yang besar berkonsekuensi kepada semakin besarnya jumlah tenaga kerja yang membutuhkan lapangan kerja.

Pada tahun 2011 total banyaknya industri Besar Sedang di kota Medan 152 unit usaha dan pada tahun berikutnya 182 unit usaha dan pada tahun 2013 mengalami penurunan yaitu hanya sebanyak 169, dan naik lagi ditahun 2014176 unit usaha dan turun lagi di tahun 2015 sebanyak 163 unit usaha. Naik dan Turunnya jumlah Industri juga diikuti oleh meningkatnya penyerapan tenaga kerja yang dari tahun 2011 berjumlah 37.724 jiwa, dan pada tahun 2012 sebesar 41.345 jiwa dan terus mengalami peningkatan di tahun 2013 sebesar 39.073 jiwa, namun mengalami penurunan di tahun 2014 yaitu hanya sebanyak 39.073 jiwa dan kembali mengalami peningkatan ditahun berikutnya yaitu di tahun 2015 sebanyak 40.990 jiwa.

Selain dari pada itu kota Medan juga dikenal sebagai jalur pelayaran Selat Malaka, memiliki posisi strategis dalam kegiatan perdagangan barang dan jasa, baik perdagangan yang dilakukan di dalam negeri maupun luar negeri. Mayoritas penduduk kota Medan sekarang ialah suku Jawa, dan suku-suku dari Tapanuli (Batak, Mandailing, Karo) dan banyak pula orang keturunan India dan Tionghoa.

Dengan kondisi tersebut, maka pengembangan ekonomi kreatif perlu dijadikan sebagai sebuah acuan, untuk itu sangat diperlukan perumusan strategi pengembangan yang tepat agar industri kreatif dapat berkembang dengan baik sehingga mampu memanfaatkan potensi yang telah ada.

\subsection{Rumusan Masalah}

1. Bagaimana potensi pengembangan ekonomi kreatif di kota Medan?

2. Bagaimana pengaruh dari ekonomi kreatif dalam penyerapan tenaga kerjadi kota Medan? 


\subsection{Tujuan dan Manfaat Penelitian}

Penelitian ini bertujuan untuk menganalisis pengaruh dari ekonomi kreatif dalam penyerapan tenaga kerja di kota Medan dan manfaat penelitian ini adalah kiranya dapat digunakan sebagai bahan masukan yang berguna bagi pengambilan keputusan dimasa yang akan datang terutama buat pemerintah. Dan kiranya dapat juga memberikan informasi yang sebenarnya pada masyarakat.

\section{METODOLOGI PENELITIAN}

\section{A. Tempat Penelitian Dan Waktu}

Penelitian

Penelitian ini dilakukan di kota Medan Provinsi Sumatera Utara. Waktu penelitian selama 3 bulan yaitu : Februari, Maret dan April 2018.

\section{B. Populasi dan Sampel}

Populasi bersifat non probability atau tidak diketahui jumlahnya. dan Pengambilan sampel dipilih dengan metode "judgement sampling" dimana judgement sampling merupakan salah satu purposive sampling selain quota sampling yaitu peneliti memilih sampel berdasarkan penilaian terhadap beberapa karakteristik anggota sampel yang disesuaikan dengan maksud penelitian (Kuncoro, 2009 hal,139). Disini peneliti akan mengambil sampel sebanyak 40 pelaku usaha ekonomi kreatif yang berada di kota Medan.

\section{Sumber Data}

\section{Data Primer}

Untuk memperoleh data primer, peneliti mengumpulkannya secara langsung melalui hasil wawancara langsung dalam bentuk wawancara personal (personal interviewing) dimana pewawancara akan menanyakan langsung kepada narasumber melalui daftar pertanyaan yang telah dipersiapkan sebelumnya.

\section{Data Sekunder}

Data sekunder bersumber dari Badan Pusat Statistik (BPS), Departemen perdagangan, jurnal buku, laporan dan lain sebagainya.

D. Teknik Pengumpulan Data

Teknik pengumpulan data dengan : Studi Pustaka, Wawancara dan kuesioner.

\section{E. Teknik Analisis Data}

Oleh karena penelitian ini bersifat deskriptif maka penulis hanya mengevaluasi berapa penyerapan tenaga kerja oleh tiap pemilik usaha ekonomi kreatif dalam bentuk quesioner atau wawancara. Secara deskriptif adalah merumuskan dan menafsirkan data yang diperoleh, mengalokasikan, menganalisis dan mengadakan interprestasi sehingga memberikan gambaran yang nyata bagi masalah yang dihadapi .

\section{HASIL DAN PEMBAHASAN}

\section{A. Karakteristik Responden}

Dalam penelitian ini, peneliti melakukan wawancara langsung kepada 40 responden yang bergerak di bidang usaha ekonomi kreatif. Daftar pertanyaan yang disusun ditanyakan langsung kepada responden melalui kuesioner wawancara.

\section{Karakteristik Responden} Usaha Ekonomi Kreatif Berdasarkan Jenis Subsektor Industri Kreatif.

Berdasarkan data yang diperoleh pada 40 responden usaha ekonomi 
kreatif yang berada di Kota Medan, terdapat 4 jenis subsektor usaha dari 18 jenis subsektor usaha kreatif yang dijalankan pada jenis usaha industri kreatif.

Tabel 3.1. Distribusi Sampel

Berdasarkan Jenis Usaha Subsektor Industri Kreatif di kota Medan .

\begin{tabular}{llrr}
\hline No & $\begin{array}{c}\text { Subsektor } \\
\text { industri }\end{array}$ & Orang & \multicolumn{1}{c}{$\begin{array}{c}\text { Persen } \\
(\%)\end{array}$} \\
\hline 1. & Kerajinan & $\begin{array}{r}21 \\
\text { orang }\end{array}$ & $52,5 \%$ \\
\hline 2. & Kuliner & 7 orang & $17,5 \%$ \\
\hline 3. & Fashion & 6 orang & $15 \%$ \\
\hline 4. & Percetakan & 6 orang & $15 \%$ \\
\hline & Jumlah & $\begin{array}{r}40 \\
\text { orang }\end{array}$ & $100 \%$ \\
\hline
\end{tabular}

Sumber : Diolah, 2018.

Dari 40 responden yang diteliti sebanyak 21 orang $(25,5 \%)$ usaha yang dijalankan bergerak di industri kreatif, dengan produk unggulan kerajinan membuat bouquet bunga, dan kerajinan dari bahan bambu. dilanjutkan kuliner yang menjadi urutan ke-2 yaitu sebanyak 7 orang $(17,5 \%)$ yang menjalankan usaha dibidang kuliner. Selanjutnya percetakan dan fashion yang samasama berjumlah 6 orang (15\%).

\section{Karakteristik Responden Usaha Ekonomi Kreatif Berdasarkan Usia}

Usia responden yang menjadi sampel dalam penelitian ini berkisar 20-55 tahun, hal ini ditunjukkan melalui pendistribusian sampel penelitian berikut ini.

Tabel 3.2 Karekteristik Responden Berdasarkan Usia

\begin{tabular}{cccc}
\hline No & Usia & Orang & $\begin{array}{c}\text { Persen } \\
(\%)\end{array}$ \\
\hline 1. & $20-25$ & 14 & 35 \\
\hline
\end{tabular}

\begin{tabular}{cccc}
\hline 2. & $26-30$ & 4 & 10 \\
\hline 3. & $31-35$ & 9 & 22,5 \\
\hline 4. & $36-40$ & 5 & 12,5 \\
\hline 5. & $41-45$ & 3 & 7,5 \\
\hline 6. & $46-50$ & 2 & 5 \\
\hline 7. & $51-55$ & 3 & 7,5 \\
\hline & Jumlah & 40 & 100 \\
\hline
\end{tabular}

Sumber : Diolah, 2018.

Dilihat dari usia responden, usia 20 - 25 tahun paling dominan dalam penelitian ini yaitu sebanyak 14 orang atau $35 \%$, yang selanjutnya disusul oleh usia 31- 35 tahun sebanyak 9 orang atau 22,5\%, kemudian disusul oleh kelompok usia 36 - 40 tahun yang berjumlah 5 orang $(12,5 \%)$ selanjutnya disusul oleh kelompok umur 26 - 30 yang berjumlah 4 orang $(10 \%)$, lalu pada kelompok umur 41 45 tahun dan kelompok umur 51 - 55 tahun berjumlah 3 orang $(7,5 \%)$, kemudian di urutan paling akhir adalah pada kelompok usia 46 - 50 tahun yang berjumlah hanya 2 orang $(5 \%)$.

\section{Komposisi Usaha Ekonomi Kreatif Berdasarkan Jenis KelaminResponden}

Komposisi ini menunjukkan perbandingan sampel jenis kelamin responden penelitian terhadap subsektor industri kreatif yang berada di kota Medan. Berikut tabel dan gambar distribusi sampel berdasarkan jenis kelamin.

Tabel 3.3 Distribusi Sampel Berdasarkan Jenis Kelamin

\begin{tabular}{cccc}
\hline No & $\begin{array}{c}\text { Jenis } \\
\text { kelamin }\end{array}$ & Orang & Persen \\
\hline 1 & Laki - laki & 23 & 57,5 \\
\hline 2 & Perempuan & 17 & 42,5 \\
\hline & Jumlah & 40 & 100 \\
\hline Sumber : Diolah , 2018
\end{tabular}

Sumber : Diolah , 2018 
Dari tabel diatas dapat kita lihat bahwa laki-laki paling banyak jumlahnya sebagai pemilik industri ekonomi kreatif di kota Medan yaitu sebanyak $57,5 \%$ (23 orang) dan jumlah pemilik usaha industri kreatif di kota Medan yang perempuan berjumlah $42,5 \%$ (17 orang).

\section{Komposisi Usaha Ekonomi Kreatif Berdasarkan Tingkat Pendidikan Responden}

Tingkat pendidikan responden merupakan bagian dari penentuan sampel penelitian sebagai acuan untuk mengetahui hubungan jenis usaha yang dijalankannya dengan tingkat pendidikan terakhir yang dilalui oleh responden. Hal ini ditunjukkan melalui tabel dan gambar distribusi sampel responden berikut ini.

Tabel 3.4 Distribusi Sampel Berdasarkan Tingkat Pendidikan

\begin{tabular}{|c|c|c|c|}
\hline No & $\begin{array}{c}\text { Tingkat } \\
\text { Pendidikan }\end{array}$ & Orang & $\begin{array}{c}\text { Persen } \\
\%\end{array}$ \\
\hline 1. & SD & 1 & 2,5 \\
\hline 2. & SMP & 1 & 2,5 \\
\hline 3. & SMA & 14 & 35 \\
\hline 4. & $\begin{array}{l}\text { Akademi } \\
\text { (D1,D2,D3) }\end{array}$ & 3 & 7,5 \\
\hline 5. & $\begin{array}{l}\text { Strata ( } \\
\text { S1,S2,S3 ) }\end{array}$ & 21 & 52,5 \\
\hline & Jumlah & 40 & 100 \\
\hline
\end{tabular}

Sumber : Diolah, 2018.

Tingkat pendidikan responden dari penelitian ini paling banyak didominasi oleh lulusan Strata S1 yaitu sebanyak 21 orang $(52,5 \%)$, kemudian disusul dari tamatan SMA sebanyak 14 orang (35\%), kemudian disusul dari tamatan Akademi ( D1,D2,D3 ) sebanyak 3 orang (7,5\%) dan kemudia terakhir oleh lulusan SD dan SMP yang masing-masing berjumlah 1 orang $(2,5 \%)$.

\section{Potensi Pengembangan Ekonomi Kreatif dari Aspek Tenaga Kerja}

Ketenagakerjaan merupakan aspek yang mendasar pada keberlangsungan kegiatan unit usaha. Dalam prakteknya, tenaga kerja banyak dijadikan sebagai alat pengukur kondisi perkembangan usaha yang secara mikro akan mempengaruhi produktivitas perusahaan. Secara teori, ketenagakerjaan memiliki peranan penting sebagai salah satu faktor produksi atau dengan kata lain tenaga kerja sebagai motor penggerak produksi unit usaha yang memainkan peranan penting dalam proses kegiatan ekonomi.

Perekonomian Kota Medan sejatinya mempunyai potensi yang sangat besar dari penyediaan jumlah tenaga kerja. Hal ini dapat diketahui dari jumlah populasi penduduk kota Medan yang sangat besar serta perbandingan angkatan kerja yang lebih banyak jika dibandingkan dengan daerah lain di Indonesia. Salah satu aspek terpenting untuk mengetahui kondisi perekonomian di kota Medan dapat dijumpai pada sektor rill serta industri yang secara umum mampu memberi sumbangsi besar terhadap penyerapan tenaga kerja.

Dari beberapa sektor yang terkait dengan subsektor industri kreatif di kota Medan, secara umum menunjukkan tren yang sangat baik, terutama berasal dari penyerapan dan penyediaan tenaga kerja baru. Hal ini ditunjukkan melalui tabel 3.4 tentang potensi pengembangan industri kreatif yang dilihat dari aspek tenaga kerja. 
Tabel 3.4 Distribusi Responden Menurut Jumlah Tenaga Kerja

\begin{tabular}{cccc}
\hline $\begin{array}{c}\mathrm{N} \\
\mathrm{o}\end{array}$ & $\begin{array}{c}\text { Subsektor } \\
\text { industri }\end{array}$ & $\begin{array}{c}\text { Jumlah } \\
\text { Responde } \\
\mathrm{n}\end{array}$ & $\begin{array}{c}\text { Jumla } \\
\mathrm{h} \\
\text { tenaga } \\
\text { kerja }\end{array}$ \\
\hline 1. & Kerajinan & 21 & $\begin{array}{c}89 \\
\text { orang }\end{array}$ \\
\hline 2. & Fashion & 6 & $\begin{array}{c}21 \\
\text { orang }\end{array}$ \\
\hline 3. & $\begin{array}{c}\text { Penerbita } \\
\text { n dan } \\
\text { Percetaka } \\
\text { n }\end{array}$ & 6 & $\begin{array}{c}28 \\
\text { orang }\end{array}$ \\
\hline 4. & Kuliner & 7 & 60 \\
& orang \\
\hline & Jumlah & 40 & 198 \\
\hline
\end{tabular}

Sumber : Diolah, 2018.

Tabel 3.4 menunjukkan bahwa pada sektor industri kerajinan paling banyak menyerap tenaga kerja yaitu sebanyak 89 orang, yang kemudian disusul oleh sektor industri kuliner dimana tenaga kerjanya terserap sebanyak 60 orang, kemudian disusul oleh sektor industri penerbitan dan percetakan yang menyerap tenaga kerja sebanyak 28 orang dan terakhir oleh sektor industri fashion yang menyerap tenaga kerja sebanyak 1 orang sehingga total tenaga kerja yang terserap dan bekerja dari 40 reponden adalah 198 orang.

Jika diperhatikan, berdasarkan data di atas maka dapat diumpamakan, setiap penambahan satu unit usaha industri kreatif di bidang manapun akan berpengaruh terhadap terbukanya lapangan kerja baru bagi masyarakat, sehingga jika banyaknya tenaga kerja yang terserap maka akan mengurangi jumlah pengangguran dan bukan tidak mungkin peluang masyarakat untuk meningkatkan taraf hidupnya akan mudah untuk diwujudkan melalui usaha kreatif yang dibangun oleh para pengusaha industri tersebut.

Dilain hal, fenomena tersebut juga akan mampu untuk meningkatkan pendapatan masyarakat, yang pada akhirnya akan meningkatkan konsumsi nasional. Pihak pelaku usaha juga akan dengan mudah meningkatkan produksinya sebab konsumsi yang tinggi dari dampak peningkatan kesehjatraan tersebut, sehingga pendapatan nasional akan mengalami peningkatan yang dilihat dari proses pembangunan perekonomian secara keseluruhan.

Sebaliknya, jika hal ini tidak dapat dimanfaatkan maka keadaan akan berubah yang berakibat pada macetnya pembangunan daerah yang disebabkan kondisi masyarakat yang masih sangat jauh dari kesehjatraan, hal ini dilihat pada tingkat pendapatan yang masih rendah akibat tidak adanya peluang pekerjaan dalam pemenuhan kebutuhan sehari-hari. Maka, dengan itu kerjasama antara pihak pemerintah, swasta dan masyarakat sangat dibutuhkan demi keberlangsungan usaha kreatif dalam mendukung dan mengembangkan potensi yang dimilikinya.

\section{Strategi Pengembangan Potensi Ekonomi Kreatif}

Dalam menentukan strategi pengembangan potensi ekonomi kreatif di kota Medan, dapat diketahui melalui kondisi usaha ekonomi kreatif yang berada di kota Medan. Kondisi tersebut dapat dilihat dari gambaran usaha, potensi dan permasalahan yang saat ini menjadi tantangan dalam perkembangan ekonomi kreatif di kota Medan. Secara umum dari total 40 responden mengungkapkan bahwa kegiatan usaha yang mereka jalani 
bersumber dari modal sendiri, hal ini diutarakan oleh 35 responden atau sekitar $83,3 \%$ dan sebanyak 7 orang responden atau sekitar $16,6 \%$ mengungkapkan bahwa modal yang mereka miliki dalam memulai usaha berasal dari modal pinjaman dan modal pribadi yang mereka miliki (campuran). Hal ini diketahui pada tabel 3.5.

Tabel 3.5

Sumber Modal Pelaku Usaha

\begin{tabular}{cccc}
\hline No & Sumber & Orang & $\begin{array}{c}\text { Persen } \\
\%\end{array}$ \\
\hline 1. & Pribadi & 28 & 70 \\
\hline 2. & Campuran & 12 & 30 \\
\hline & Jumlah & 40 & 100 \\
\hline
\end{tabular}

Sumber : Diolah, 2018.

Terkait dari hasil wawancara penulis menemukan bahwa beberapa responden mempunyai cabang usaha, yaitu sebanyak 12 responden mempunyai cabang usahanya yang sejenis. Selain itu juga dari hasil wawancara penulis menemukan beberapa permasalahan dari reponden diantaranya mahalnya uang untuk sewa toko yang memiliki ukuran sedang dan juga kurangnya cara promosi dan ada juga semakin susah mendapatkan bahan baku pembuatan produknya.

\section{DAFTAR PUSTAKA}

Badan Pusat Statistik. (2014). Medan Dalam Angka tahun 2014. Medan : Badan Pusat Statistik Kota Medan.

Badan Pusat Statistik. (2017). Medan Dalam Angka tahun 2016. Medan : Badan Pusat Statistik Kota Medan.

\section{KESIMPULAN}

1. Potensi dari usaha yang berbasis ekonomi kreatif

a. Dilihat dari aspek tenaga kerja rata-rata mampu menyerap sebanyak tenaga kerja 1-30 tenaga kerja pada setiap bidang usaha. Dengan total tenaga kerja paling banyak diserap berasal dari industri kerajinan sebanyak 89 orang .

b. Dilihat dari Aspek umur, resonden usia 20 - 25 tahun yang paling dominan jumlahnya.

c. Berdasarkan jenis kelamin, pemilik usaha ekonomi industri kreatif paling banyak berjenis kelamin laki-laki .

d. Berdasarkan tingkat kelulusan pemilik usaha industri kreatif, tingkat kelulusan di paling banyak adalah lulusan Strata S1 (Sarjana).

2. Pengaruh dari ekonomi kreatif dalam penyerapan tenaga kerja adalah bahwa ekonomi kreatif mampu menyerap paling sedikit 1 orang dan paling banyak 30 orang di setiap satu sektor industri kreatif. Maka dalam 40 sampel industri kreatif di kota Medan mampu menyerap 198 tenaga kerja.

Badan Pusat Statistik. (2015). Sumatra Utara Dalam Angka tahun 2015. Medan, Badan Pusat Statistik Kota Sumatra Utara.

Danuar, Dani. (2013). Pengembangan Usaha Mikro Kecil dan Menengah (UMKM) Berbasis Ekonomi Kreatif di Kota Semarang.Semarang. 
Kementrian Pariwisata dan Ekonomi Kreatif. (2014). Ekonomi Kreatif : Kekuatan Baru Indonesia Menuju 2025, Jakarta : Kementrian Pariwisata dan Ekonomi Kreatif RI.

Kuncoro, Mudrajat (2009). Edisi 4. Metode Riset untuk Bisnis \& Ekonomi,bagaimana meneliti dan menulis Tesis , Jakarta : Erlangga.
Seputar Wirausaha. (2014). Defenisi Ekonomi Kreatif. http://arifh.blogdetik.com/ $\quad(17$ Februari 2018)

Thecolourofindonesia. (2016). Kota terbaik bagi industri kreatif. http ://kota terbaik bagi industri kreatif.com html (15 November 2016 ). 